\title{
La Vita Christi d'Isabel de Villena, misericòrdia restaurativa i profitosa doctrina al servei de la meditació
}

\section{The Vita Christi of Isabel de Villena, restorative mercy and profitable doctrine in the service of meditation}

\author{
Anna Isabel Peirats Navarro \\ anna.peirats@ucv.es
}

Universidad Católica de Valencia San Vicente Mártir

Resum: Aquest article se centra en la intencionalitat de la Vita Christi d'Isabel de Villena, a partir dels aspectes controvertits que han sigut objecte de comentaris per part de la crítica literària, com ara la constant presència de les dones que envolten la vida de Jesucrist, així com el recurs a l'estil afectiu, pietós i emotiu que s'hi evidencia, i que hom ha considerat com a exponents de literatura profeminista o de gènere. En aquestes pàgines s'aporta una lectura de la Vita Christi basada en la influència del corrent espiritual de la devotio moderna, a mode d'ars meditandi, alhora que es reflexiona al voltant del propòsit doctrinal i didàctic de l'obra, en què la presència de les imatges femenines, que ara són redimides, així com de les imatges masculines, a les quals es concedeix el reconeixement pels actes virtuosos o el perdó per les faltes comeses, es justifica des de la misericòrdia restaurativa i la clemència divina, com a exemple a seguir per les monges, que són les receptores primeres de l'obra.

Paraules clau: misericòrdia restaurativa, feminisme, doctrina, meditació, Vita Christi.

\begin{abstract}
This article focuses on the intentionality of the Vita Christi of Isabel de Villena, based on the controversial aspects that have been the subject of comments by literary criticism, such as the constant presence of women surrounding the life of Jesus Christ, as well as the resource in the emotional, pious and emotional style that is evident, and that has been considered as exponents of prophecy or gender literature. These pages provide a reading of the Vita Christi based on the influence of the spiritual current of the devotio moderna, as ars meditandi, while reflecting on the doctrinal and didactic purpose of the work, in which the The presence of the feminine images, which are now redeemed, as well as the masculine images, to which recognition is granted for virtuous acts or forgiveness for the offenses committed, is justified from restorative mercy and divine mercy, as an example of continue for the nuns, who are the first recipients of the work.
\end{abstract}

Keywords: restorative mercy, feminism, doctrine, meditation, Vita Christi

\footnotetext{
* Aquest article s'emmarca en el grup d’investigació núm. 188 del Departament de Llengua i Literatura de la Universidad Católica de Valencia.
} 


\section{Anna Isabel Peirats Navarro. La Vita Christi d'Isabel de Villena, misericòrdia restaurativa i profitosa doctrina al servei de la meditació}

\section{Introducció}

Des dels inicis del cristianisme, una tendència que perdura en el transcurs dels segles és la voluntat d'adoctrinament per part de l'Església, com a punt imprescindible per tal de reflexionar i actuar, a partir del coneixement de la missió redemptora de Crist. Respecte de la Verge Maria, com a intercessora per tal d'assolir la gràcia divina, durant els segles XI i XII l'Església va centrar no pocs esforços a exaltar aquesta figura, fins que amb la difusió de les idees del franciscanisme es va atorgar major rellevància a subratllar la figura de Crist $i$, doncs, a atribuir un valor primordial al cristocentrisme, model a imitar quant als valors de pobresa, humilitat i castedat, com a norma de conducta moral.

Pel que fa a la llengua, tot i que en els inicis el llatí era l'idioma habitual de la predicació, amb les aportacions del franciscanisme aquesta tendència es va capgirar a favor de l'ús de les llengües vernacles, per tal com es considerava fonamental que els receptors, no massa avesats a l'erudició i a les citacions llatines, participaren del missatge evangèlic, des de l'evidència que les paraules de Crist no eren allunyades (Merino 1982), sinó adreçades precisament a tota la societat, sense distincions. En aquest context, d'exaltació del cristocentrisme, destaca la Vita Christi de Ludolf de Saxònia, al segle XIV, concebuda com una obra de meditació, més que una simple biografia de Crist (Bodenstedt 1944) i en català la Vita Christi de Francesc Eiximenis.

Tot $\mathrm{i}$ aquests precedents, i de l'impacte que van generar les obres de Ludolf i d'Eiximenis, al segle $\mathrm{XV}$ va esdevenir un canvi substancial amb la Vita Christi d'Isabel de Villena, tant pel que fa a l'estil i a l'estructura narrativa com pel fet de ser una vida de Jesucrist, escrita per una dona amb una vasta formació teològica.

Elionor d'Aragó ${ }^{1}$ (1430-1490), més tard Isabel de Villena, en prendre l'hàbit de clarissa, era filla il legítima d'Enric de Villena ${ }^{2}$, després de la mort del qual, i a l'edat de quatre anys, va ser acollida per Maria de Castella, esposa d'Alfons el Magnànim, que la va criar en un ambient reial (Narbona 2009), i es va preocupar perquè fóra educada en una estricta moralitat. És així com, tenint en compte els escàndols que s'esdevingueren al monestir dels trinitaris (Escartí 2011), la reina va decidir gestionar el canvi d'aquell monestir, que estaria dirigit per monges clarisses ${ }^{3}$, i es convertiria en centre d'espiritualitat de València. I el mateix any en què es va fundar el monestir, i a l'edat de

1 Respecte al nom d'Isabel de Villena, ja va deixar constància Riquer (1985: IV, 315) que és erroni anomenar-la Elionor Manuel de Villena.

2 Enric de Villena, autor de Los Dotze treballs d'Hèrcules (Cátedra 1994) era fill de Pere d'Aragó i de Joana, filla d'Enric II de Castella. L'obra d'Enric de Villena va ser aprofitada per Martorell per tal de redactar la dedicatòria del Tirant lo Blanch (Martorell 2003).

3 En la construcció del monestir van participar personatges il lustres i lletraferits, com ara Ausiàs March, Joan Roís de Corella, Miquel Peres o el mateix Jaume Roig, que va ser-ne administrador. Tal com esmenta Escartí (2011: 18) al pròleg a la seua edició de la Vita Christi, el dietarista Melcior Miralles fa referència, en data de 9 de juliol de 1445, als inicis de l'edificació del convent.. 


\section{Anna Isabel Peirats Navarro. La Vita Christi d'Isabel de Villena, misericòrdia restaurativa i profitosa doctrina al servei de la meditació}

quinze anys, Isabel d'Aragó va ingressar com a novícia; com a conseqüència de la seua vocació ${ }^{4}$ i de la seua capacitat de gestió va esdevenir abadessa (des de 1462 fins a la seua mort) i va tindre un paper fonamental a l'hora d'aconseguir donatius i de servir de model per a les noves vocacions de filles de les famílies més prestigioses de València ${ }^{5}$.

Conscient del sacrifici que, en no poques avinenteses, suposava per a les jóvens nobles ingressar en un monestir, sor Isabel, que sentia la imperiosa necessitat d'instruir les monges que havien renunciat a una vida ostentosa per una d'austera entre les parets del monestir, va escriure una Vita Christi, per tal que les monges se sentiren part fonamental en la història de la Redempció, i mitjançant la paraula s’inclinaren a la meditació i als exercicis pietosos, tal com recull Sales (1761: 91):

Es obra de mucha habilidad, juicio y piedad, correspondiente a lo que la misma venerable sor Villena escrivió en la Vida de Christo, tratando puntos mui elevados. Usan de esta obra las religiosas para sus meditaciones i egercicios de piedad, pero digna de que se conservara en el archivo, para su mayor perpetuidad i duración.

En aquestes pàgines es partix de l'objectiu de reflexionar, en primer lloc, sobre la intencionalitat de la Vita Christi de Villena, i, doncs, argumentar per què l'abadessa va escriure la seua obra amb un determinat estil (feminista/afectiu/femení?); per què la vida de Jesucrist està escrita amb una especial consideració envers les dones i quin és el sentit de tractar com a dignes i virtuoses dones com la mateixa Eva, la qual havia sigut objecte de denigració des del corrent misogin, tant des dels Pares de l'Església com de tota la literatura medieval, escrita sempre per una ploma masculina.

\section{Intencionalitat de la Vita Christi}

Pel que fa a la intencionalitat de la Vita Christi, cal parar esment al fet extraordinari i gens usual que una dona escriguera a l'Edat Mitjana una obra i que, a més, plantejara la vida de Jesucrist amb especial atenció a la figura femenina, sobretot de la Verge Maria, en un context en què la literatura estava immersa en el corrent misogin, àmpliament difòs en tots els àmbits de la societat. Aquesta incògnita, per tal d'argumentar què va motivar la monja valenciana a escriure la seua obra ha sigut motiu de diverses interpretacions, com Fuster (1995: 68), que hi subratlla «una veritable

\footnotetext{
4A l'Edat Mitjana, l'entrada al monestir suposava una destinació segura i àmpliament recurrent en casos en què les famílies no consideraven oportú unir en matrimoni les seues filles, o més aviat no disposaven de suficients recursos per a aportar la dot requerida. Tot i aquesta realitat, és obvi que en nombroses ocasions les joves optaven per la vida monàstica per devoció i voluntat pròpia, com de segur va ser el cas d’Isabel de Villena (Hauf 1995).

5 La seua gestió i total entrega vocacional arribà al punt que sor Isabel va tindre un paper fonamental en l'ampliació i en el creixement econòmic del monestir, a més que va esdevenir un referent de prestigi per a les màximes autoritats civils i eclesiàstiques, que requerien els seus consells, per tal com la consideraven un referent en el vessant intel lectual. No s'ha d'oblidar que Isabel de Villena va rebre dedicatòries en les obres d'alguns intel lectuals del moment (Escartí 2011), com ara Miquel Peres, a la Imitació de Jesucrist, o Bernat Fenollar a Lo passi en cobles.
} 
consciència de feminitat, amatent i desperta, gairebé polèmica, que jo no vacil laria a qualificar de feminista, tot i que el mot resulta angoixosament anacrònic». En efecte, l'obra de Villena no es pot considerar com a feminista, perquè cronològicament no és possible atribuir aquest terme al segle XV. Seguint el raonament, Fuster (1995: 68) argumentava que sor Isabel reaccionava «només per satisfacció interior als versos violents de l'Espillı) o, com apunta Cantavella (2011) a escriure una obra que esdevé una apologia de la superioritat de la dona com a rèplica autèntica a l'Spill de Roig; hom ha arribat a apuntar que la Vita Christi és una obra del corrent profeminista, en defensa de la dignitat de les dones (Cantavella 2005).

Anem per parts: Isabel de Villena coneixia el metge autor de l'Espill, en primer lloc perquè Roig havia sigut metge de la reina Maria, a més de la seua vinculació al convent de la Trinitat, primer com a metge i administrador, així com pel fet que una filla seua, Violant, va ingressar al convent (Peirats 2010). En aquest sentit, Fuster apunta que cronològicament seria probable que l'abadessa, que va compondre la seua obra a la fi de la seua vida, haguera conegut l'obra de Roig, tot i que matisa alhora que «l'Espill no sembla una lectura massa pròpia d'abadesses» (1995: 106); en tot cas, es planteja Fuster si l'abadessa n'hauria pogut ser informada per algun dels lletraferits valencians del moment que li dedicaven llibres pietosos.

De més a més, i tenint en compte la vasta formació de sor Isabel de Villena, no cal dir que l'abadessa coneixia, com a dona intel lectual, els fonaments de la literatura de caire misogin, des de la lectura dels sants Pares i els textos bíblics, així com el mateix debat literari o querelle des femmes (Cantavella 1987), que abraça el període dels segles XIV al XVIII. Aquest debat se centrava en la defensa de la capacitat intel lectual de les dones, amb la qual cosa es consolidava en el vessant literari la igualtat d'ambdós gèneres, després dels segles en què la dona havia estat devaluada i considerada com un ser vil i maleït (Peirats 2019). El debat, que es va fer públic en les tertúlies literàries i es va aprofitar com a farciment de no poques obres que reivindicaven la dignitat femenina, es va encetar amb l'obra de Christine de Pizan (1405, eds. Hicks i Moreau 1986), la Cité des dammes, en resposta a la visió denigratòria i misògina del Roman de la Rose de Jean de Meun i Guillaume de Lorris (1245) escrita en vers, obra cortesana que denigrava la dona i la considerava com a vil i menyspreable, en clau de dues al legories, la Raó i la Fortuna. Aquest estil i estructura són ben aprofitats per Christine de Pizan a La cité des dames, obra escrita en la forma del tractat medieval, típic dels debats literaris, ${ }^{6}$

6En el cap. 1 de La cité des dames es fa explícit per part de l'autora el desig de rebatre les opinions denigratòries dels autors anteriors: «Me preguntaba cuáles podrían ser las razones que llevan a tantos hombres, clérigos y laicos, a vituperar a las mujeres, criticándolas bien de palabra bien en escritos y tratados. No es que sea cosa de un hombre o dos, ni siquiera se trata de ese Mateolo, que nunca gozará de consideración porque su opúsculo no va más allá de la mofa, sino que no hay texto que esté exento de misoginia. Al contrario, filósofos, poetas, moralistas, todos -y la lista sería demasiado larga- parecen hablar con la misma voz para llegar a la conclusión de que la mujer, mala por esencia y naturaleza, siempre se inclina hacia el vicio. Volviendo sobre todas esas cosas en mi mente, yo, que he nacido mujer, me puse a examinar mi carácter y mi conducta y también la de otras muchas mujeres que he tenido ocasión de frecuentar, tanto princesas y grandes damas como mujeres de mediana y modesta condición, que tuvieron a bien confiarme sus pensamientos más íntimos. Me propuse decidir, en conciencia, si el testimonio reunido por tantos varones ilustres 


\section{Anna Isabel Peirats Navarro. La Vita Christi d'Isabel de Villena, misericòrdia restaurativa i profitosa doctrina al servei de la meditació}

dividida en tres parts, en què tant la Raó com la Fortuna són al legories segons les quals la raó superarà els prejudicis contra les dones a fi de construir una ciutat justa, alhora que es ressaltaran també els valors de la Fortuna, amb atributs com la fidelitat, l’amor i la justícia.

Un segle més endavant, al segle XVI, i en un context humanista i venecià, hi destacaren algunes dones capdavanteres en la producció de literatura profeminista, com ara Moderata Fonte (Il merito delle donne, 1600) i Lucrezia Marinella (La nobiltà et l'eccellenz̧a delle donne, co'diffetti et mancamenti degli buomini, completada en 1601), amb obres d'una sòlida formació literària i d'una alta qualitat (Broad i Green 2009; Peirats 2019), que es basaven en una nova forma d'interpretar els textos anteriors, des d'una perspectiva crítica i apologètica. Tal com s'analitza en Peirats (2019), l'obra de Lucrezia Marinella respon a un tractat misogin escrit per Giuseppe Passi en 1599, sobre els defectes de les dones (I donneschi diffetti) escrit a mode de tractat medieval i en la forma del discurs, on s'argumenten els defectes i els vicis i es vilipendia el gènere femení, d'acord amb l'ideari comú al corrent misogin. En aquest vessant, la resposta de Lucrezia es presenta en la mateixa forma del tractat ${ }^{7}$, a l'estil del seu predecessor, al qual vol superar quant a demostració de la dignitat de les dones, amb la qual cosa l'obra s'estructura de manera paral lela al tractat de Passi, però a contrario. A més a més, i és una tendència compartida també per Moderata Fonte i Arcangela Tarabotti, s'explicita al pròleg la intencionalitat de respondre a Giuseppe Passi (Peirats 2019). És a dir, Lucrezia presenta una rèplica contundent $\mathrm{i}$ raonada al text anterior $\mathrm{i}$, com és evident, compon el seu text amb la mateixa estructura, forma i estil literari.

Amb tot, les obres emblemàtiques del profeminisme, tant l'obra de Pizan com les de les humanistes venecianes del segle XVI tenen en comú l'explicitació en el mateix pròleg que es disposen a rebatre els arguments dels textos anteriors, i presenten la seua argumentació amb el mateix tipus d'estil, forma i estructura.

No és aquest el cas de la intencionalitat de la Vita Christi d'Isabel de Villena, que dista de poder considerar-se una rèplica a l'Spill, per diversos motius: si ens centrem en l'obra de Jaume Roig, cal esmentar que està escrita en el gènere de les noves rimades migpartides (Peirats 2010), que consisteix en l'acumulació de tirallongues de versos tetrasíl labs apariats, més de 16000 versos, organitzats d'acord amb la forma externa d'un sermó ${ }^{8}$. L'obra presenta una estructura interna en quatre parts o llibres principals, i narra una història narrativa fictícia, escrita en la forma d'un jo pseudoautobiogràfic. Els destinataris de l'Spill, des del mateix pròleg, són els hòmens, als quals el

podría estar equivocado» (I: 64). Fem servir la traducció castellana per a una millor comprensió del passatge.

7 Marinella va conrear diversos gèneres, des dels comentaris filosòfics, la poesia, les obres religioses i espirituals, amb obres com La colomba sacra (1595), Vita del serafico et glorioso S. Francesco con Il Discorso del rivolgimento amoroso verso la somma Bellezza (1597), Vita di Maria Vergine, així com una obra de ressò pastoril, Arcadia Felice. Però va emprar el recurs al tractat medieval per a compondre la seua rèplica a Giuseppe Passi (Peirats 2019).

8 L'obra inicia amb la recurrència a un tema bíblic, una lectura del Ct 2, 2 «sicut lilium inter spinas, sic amica mea inter fillias».

SCRIPTA, Revista internacional de literatura i cultura medieval i moderna, núm. 14 / desembre 2019 /pp. 205 - 228 ISSN: $2340-4841 \cdot$ doi:10.7203/SCRIPTA.14.16366 


\title{
Anna Isabel Peirats Navarro. La Vita Christi d'Isabel de Villena, misericòrdia restaurativa i profitosa doctrina al servei de la meditació
}

jo poètic pretén adoctrinar i convéncer del perill que suposa unir-se a les dones, i de com resulta de beneficiós renunciar-hi i dedicar-se a la meditació, com a garantia de salvació espiritual. ${ }^{9}$

Així, doncs, Roig escriu el seu Spill, a mode de sermó, amb una finalitat didàctica, i planteja el seu llibre des de l'inici d'acord amb la intenció de complir una obra de misericòrdia, ensenyar a qui no $\operatorname{sap}^{10}$. A més d'aquestes característiques tot just esmentades, l'Spill narra externament la història d'un camí iniciàtic d'un personatge fictici que emprén un camí a la recerca dels designis de la fortuna, en què resulta malparat, fins que rep en somnis la visita terapèutica de Salomó, que l'aconsella i persuadeix dels perills d'unir-se a les dones, amb un repàs argumentat, des de la mateixa creació d'Adam i Eva fins a la ressurrecció de Crist.

Si fem un pas endavant, pel que fa a la Vita Christi, cal parar esment, en primer lloc, que l'obra de Villena està escrita en forma narrativa, atés que es tracta d'una vida de Jesucrist, no una història fictícia, els destinataris de la qual són les dones, en concret, les monges del convent, segons esmenta al pròleg Aldonça de Montsoriu, successora de sor Isabel de Villena, en la dedicatòria ${ }^{11}$ a Isabel la Catòlica de l'edició de la Vita Christi de 1497:

\begin{abstract}
Ella, devotíssima mare, ha volgut sembrar en lo blanc paper d'aquest libre la llavor de la sua apurada consciència, perquè los qui el llegissen poguessen collir fruit de profitosa doctrina, suplicant al gran rei Jesús volgués ésser lo nauxer i pilot de la barca de son entendre (...). Sor Isabel de Villena lo ha fet; Sor Isabel de Villena l'ha compost; Sor Isabel de Villena, ab elegant i dolç estil, l'ha ordenat, no solament per a les devotes sors i filles d'obediència que en la tancada casa d'aquest monestir habiten, mas encara per a tots los qui en aquesta breu, enutjosa e transitòria vida viuen (Villena 2011: 51-52).
\end{abstract}

Per tant, les receptores de la Vita Christi són, d’entrada, les monges del convent de la Trinitat, a les quals pretenia adoctrinar i induir a la contemplació; i en segona instància, la resta de lectors que necessitarien incrementar la devoció o, en termes del mateix Fuster (1995: 52), serien «digualment ingenus i devots».

Si la Vita Christi haguera volgut considerar-se com una rèplica als versos de Roig, l'autora hauria evidenciat al pròleg, a l'estil de les obres profeministes, com ho havia fet ja Cristine de Pizan, quina era la seua intencionalitat $i$, doncs, quin era el seu objectiu de partida, i potser hauria compost la seua obra en altres coordenades temàtiques, més ajustades a un debat literari o a una resposta contundent als versos del metge valencià. A més a més, la matèria narrativa de la Vita Christi és

9 «Als poch entesos,/perquè s’i miren,/vegen hon tiren/en lo llur viure,/los vull escriure/est doctrinal/memorial:/ haurà nom Spillı (vv. 232-239).

10 Aquesta decisió autorial explica la dualitat entre moralitat i comicitat a l'obra, o entre sàtira i teologia, que conforma l'objectiu de compondre unes noves rimades aforismals (escrites a mode d'aforisme, sentències morals) i facecials (versos de caràcter groller, sarcàstic) (Peirats 2003).

11 Tant els fragments com l'ordenació dels capítols de la Vita Christi d'Isabel de Villena segueixen l'edició d'Escartí (2011). 
molt diferent a la de l'Spill, per tal com Isabel de Villena relata episodis des de la Concepció de la Verge, el seu naixement, fins al seu traspassament, després de 291 capítols, en què només s'albira l'opció d'incentivar la meditació i la contemplació de les monges, per tal que puguen «collir fruit de profitosa doctrina». Així, doncs, forma, estructura interna, objectiu i intencionalitat diversos fan pensar en una simple conjectura el fet de considerar la Vita Christi com una rèplica als versos de Jaume Roig, o que estiga escrit a mena de «diàleg llunyà i dissimulat, amb l'Espill» (Fuster 1995: 72).

\section{L'estil de la Vita Christi}

En un segon nivell d'aprofundiment, i més enllà de la temàtica i de l'estructura que s'hi narra, pel que fa a l'estil alguns crítics han coincidit a evidenciar una «sensibilitat femenina» en la Vita Christi (Fuster 1995; Cantavella 1987; Alemany 1993; Ferrando 2015), així com s’ha subratllat la condició femenina de l'autora pel que fa a l'ús d'un anomenat «estil afectiu», en què tenen cabuda els diminutius, la tendresa, i una fina sensibilitat que els crítics remarquen que només podria ser escrita per una ploma femenina, amb una «tendresa molt femenina» $\mathrm{o}$ «amb un estil de monja, en el bon sentit de l'expressió» (Riquer 1985: III, 480).

Cal parar esment, nogensmenys, que la tendresa, la humilitat, la compassió i la pietat a l'hora de considerar la humanitat de Crist són eixos fonamentals per a assolir la perfecció espiritual en el franciscanisme. En aquest punt cal remarcar que l'originalitat de la Vita Christi no és presentar una biografia més de la vida de Jesucrist, tot i que es mostra fidel als evangelis canònics i, sovint, als apòcrifs, sinó compondre una obra des del prisma selectiu d'aquelles escenes que més infongueren la pietat, la compassió, la tendresa i la devoció en les receptores a les quals s'adreçava la lectura, a partir de noves propostes imaginatives (Ferrando 2015: 32), que pretenien omplir els buits de contingut dels textos evangèlics.

I aquesta intencionalitat, clarament justificada des del mateix pròleg, s'aconsegueix mitjançant un estil que està inspirat en els recursos típics de les biografies de la vida de Jesucrist, com la vida de Crist de Ludolf de Saxònia, l'Arbor vitae crucifixae Iesu, d'Ubertí de Casale, així com les Meditationes Vitae Christi del pseudo-Bonaventura, que a mode de manual o devocionari es va traduir a la major part de les llengües d'Europa i va ser germen de propagació de la devotio moderna ${ }^{12}$. Aquest moviment espiritual, que va sorgir al segle XIV als Països Baixos, va ser impulsat per Gerard Groote (13401384) i pel seu deixeble Florenci Redewijns (1350-1400), i es va concretar en l'associació dels «germans de la vida comuna» $\mathrm{i}$ en els canonges agustins de Windesheim.

Algunes de les característiques de la devotio moderna, segons Garcia-Villoslada (1956) s'emmarquen en un cristocentrisme pràctic, seguint sant Agustí, basat en la humanitat, d’inspiració en sant Bernat,

12 La bibliografia sobre la devotio moderna era poc coneguda fins que en 1924 Hyma va situar-la en el context cultural i religiós d'Europa, tot i fer-la coetània al Renaixement, a la Reforma i a la Contrareforma (Hyma 1925).

SCRIPTA, Revista internacional de literatura i cultura medieval i moderna, núm. 14 / desembre 2019 /pp. 205 - 228 ISSN: 2340-4841 $\cdot$ doi:10.7203/SCRIPTA.14.16366 
i en la imitació en la figura de Crist, sinònim de perfecció, com a nucli de la seua espiritualitat ${ }^{13}$. A més, cal fer notar altres trets propis d'aquest moviment espiritual, com ara el biblicisme, basat en els textos de la Sagrada Escriptura i dels sants Pares; l'oració metòdica, a fi de sistematitzar l'espai i el temps dedicat a la lectio, meditatio, oratio et contemplatio i, sobretot, l'oració mental, amb especial menció al lloc, la posició i l'hora escaients per a la meditació; el moralisme intens, així com el caràcter afectiu, inspirat en obres del franciscanisme, com sant Bernat, Ludolf i Dionís el Cartoixà, sant Bonaventura i Ubertí de Casale, entre d'altres.

Tenint en compte el caràcter afectiu, la devoció ${ }^{14}$, per al corrent de la devotio moderna és «fervor, oració inflamada, desig de Déu» (Garcia-Villoslada 1956: 334) que naix del cor; per consegüent, la interioritat i el subjectivisme situen al mateix nivell l'home devot i l'home interior, com a sinònims de compunció, de dolor intern. A més, és notori en els seguidors de la devotio moderna l'apartament del món, el silenci i la soledat, com a elements indispensables; l'ascetisme, amb especial èmfasi en l'exercici de les virtuts front als vicis, des de la contemplació, a partir de l'acte de «rumiar» (Hauf 1979: 88) o meditar sobre tot el que genere temor de Déu, com el judici final o la mort a les tenebres de l'infern. En aquest punt, segons el fundador de la devotio moderna, existeixen quatre maneres de meditar: aprofitant els textos canònics, les revelacions dels sants, els arguments dels teòlegs i la fantasia i imaginació del devot, mètodes que són ben presents en les vitae christi medievals, això sí, passades pel sedàs afectiu que deixa entreveure la influència de sant Francesc i dels escrits de sant Bonaventura (Hauf 2006).

D'acord amb aquesta tendència, les Meditationes Vitae Christi, obra que influeix directament en les vitae christi catalanes, està escrit en un estil afectiu i parteix de l'objectiu d'ajudar als receptors a «imaginar» la humanitat de Crist des dels detalls més mínims, com a mitjà d’incentivar la devoció, la compassió, la tendresa i l'amor, en casos en què els mateixos Evangelis no havien parat esment. Amb aquest sistema de meditació, com a model de vida i ideari del franciscanisme, es pretenien reconstruir les llacunes de les escenes que els textos canònics no havien detallat, per tal de fomentar la contemplació. A més de la remarcable influència de les Meditationes Vitae Christi, les característiques i l'estil de la devotio moderna, cal destacar l'assimilació del Benjamin maior, manual teòric de contemplació de Ricard de sant Víctor, en la literatura catalana religiosa, a partir de l'obra de fra Antoni Canals ${ }^{15}$, Scala de contemplació.

Amb aquest rerefons, i si seguírem interpretacions basades en trets d'identitat, es podria també pretendre identificar un «esperit femení» en les Meditationes Vitae Christi, atenent a l'estil, d'una mística intimista, que també cohesiona la Vida de Jesucrist d'Eiximenis, el Tomàs de Kempis, o

13 Una de les obres més representatives de la devotio moderna és De imitatione Christi. A més, Gerard Groote, fundador de la devotio moderna, afirmava que Jesucrist ha d'estar present sempre en el nostre pensament i en el nostre cor (Garcia-Villoslada 1956: 318).

14 «Devotio est pius et humilis affectus in Deum; humilis ex conscientiae infirmitatis propriae, pius ex consideratione divinae clementiae» (De Spiritu et Anima, PL 40, 816).

15 Segons argumenta Roig Gironella (1975: 9): «tomó Canals probablemente las fuentes de la 'devotio moderna', que difundió con sus escritos en la Corona de Aragón». 


\section{Anna Isabel Peirats Navarro. La Vita Christi d'Isabel de Villena, misericòrdia restaurativa i profitosa doctrina al servei de la meditació}

la vita de Ludolf de Saxònia, traduïda en estil de valenciana prosa per Roís de Corella, o en Lo Cartoixà (1495-1500) ${ }^{16}$, obres que van ser aprofitades per l'abadessa de la Trinitat, que va emprar recursos «suposadament femenins» (Hauf 1995: 35). Nogensmenys, més que tractarse de recursos que reflecteixen feminitat o que són obra femenina, aquest estil pietós i afectiu es caracteritza per l'ús d'una prosa pensada per a commoure, imaginar i meditar, des d'un propòsit devot i catequètic, que no està intrínsecament associat al fet de ser dona (Riquer 1985; Alemany 1993; Escartí, 2011); per això el màxim detall, el patetisme i el dramatisme són presents en no poques escenes, que pretenen infondre la misericòrdia $i$ constituir un model a imitar pels receptors.

El cas d'Isabel de Villena afegeix la particularitat que, a diferència de la resta de les obres abans esmentades, compostes per hòmens $\mathrm{i}$ adreçades a un públic majoritari d'hòmens, va ser escrita per una dona i adreçada a les religioses clarisses de la Trinitat. I tal com es fa palés en les obres precedents, Villena empra un estil «afectiu» (Cantavella 2013), no femení ni reivindicatiu, sinó pietós, o tal com argumenta Orts (1991: 325) «una peculiaritat retòrico-estilística pròpia», més que com a reflex de la condició femenina, per tal de despertar la devoció i la misericòrdia de les seues religioses. A més a més, tot i mostrar la influència de les Meditationes vitae Christi, Isabel de Villena estableix la seua pròpia selecció d'escenes que remarquen els moments de la vida de Jesús, en concret, dels primers anys de la infantesa, així com de la passió, la mort i la ressurrecció de Crist en els darrers episodis, en què es remarca la tendresa i la maternitat, d'una banda, i el patetisme i el dramatisme, de l'altra, per tal de persuadir les receptores.

Aquesta clara intenció persuasiva de l'abadessa de la Trinitat, d'inspiració en les obres pietoses de meditació franciscana, condiciona abastament l'opció de l'ús de recursos estilístics presents a la Vita Christi, com a instrument de difusió de doctrina feta paraula i embolcall de la contemplació. L'abadessa de la Trinitat demostra un domini dels recursos retòrics que embelleixen el text per a incitar a la meditació.

Alguns recursos que empra sovint estan presents també en les obres de la devotio moderna ${ }^{17}$, com els binomis paratàctics («mirar-la e contemplar-la», cap. 4: 62; «mirant e contemplant», cap. 45: 178;

16 Cal remarcar que en els darrers anys s'han estudiat, editat i comentat les versions del magne treball de Lo Cartoixà de Corella: en concret, destaquem les tesis doctorals de Furió (2015) sobre la traducció corellana del llibre terç; Garcia Peris (2015), del llibre primer de Lo Cartoixà i Oviedo (2017), del llibre segon del Cartoixà.

17 Aquestos recursos també estan presents en la prosa artitzada de Miquel Peres o en lo Cartoixà de Roís de Corella, tal com remarca Arronis (2015), si bé és cert que la prosa de Villena no presenta l'estil de la valenciana prosa, per tal com destaca per la seua senzillesa (Ferrando 2015: 41), sinó que els recursos que també comparteixen aquestes obres abans esmentades participen de la tradició de les vitae christi medievals, que busquen en l'ús continu dels recursos emfàtics un determinat afecte i emoció. En aquest sentit, mentres que Corella tradueix i aprofita els recursos de la versió de Ludolf de Saxònia, Isabel de Villena assimila el text de les Meditationes vitae Christi i el transforma en realisme i en senzillesa, amb una selecció original i particular d'escenes. A més, Isabel de Villena aprofita la font del Cartoixà per als capítols sobre la passió i la mort de Crist, amb un realisme que, seguint Hauf (1979) supera els textos franciscans.

SCRIPTA, Revista internacional de literatura i cultura medieval i moderna, núm. 14 / desembre 2019 /pp. 205 - 228 ISSN: 2340-4841 · doi:10.7203/SCRIPTA.14.16366 


\title{
Anna Isabel Peirats Navarro. La Vita Christi d'Isabel de Villena, misericòrdia restaurativa i profitosa doctrina al servei de la meditació
}

cap. 48: 182; «advocada e procuradora», cap. 77: 195; «inflamada e absorta», cap. 75: 178; «dolor e pena», cap. 11: 81), les nombroses exclamacions o el recurs a les interrogacions retòriques. A més a més, crida l'atenció el constant ús del verbum dicendi que introdueix l'estil directe, sovint amb una citació en llatí, a partir de la forma «volent dir», que introdueix una traducció gens literal del text llatí, sinó una glossa amplificada amb un estil retòric, on abunden els binomis paratàctics, els incisos i la subordinació, que emfatitza el discurs narratiu, tal com es pot evidenciar, com a mostra, en l'exemple següent:

\begin{abstract}
ab molta reverència, dix: -Ne avertas faciem tuam a me qui spetiem et decorem tuum a juventute mea concupivi. Volent dir: Oh, ma senyora! No gireu la vostra cara de mi, ans si jo tostemps en la vostra amor e gràcia, car la bellea e dolçor de vostra senyoria carament he amada de la mia joventut ençà, e ab vostra mercé me só criada, e de vostra altesa me ve que sia per àngels e per hòmens coneguda i estimada; perquè dignament sereu per mi servida $\mathrm{e}$ molt lloada e magnificada, en lo cel e en la terra, on se vulla que jo sia trobada. (cap. 56: 158)
\end{abstract}

L'estil narratiu de la Vita Christi es cohesiona mitjançant un ampli microunivers supralingual, on predomina la tendència a l'adjectivació, sovint pleonàstica («amargós plant», cap. 218, p. 448), l'ús d'adjectius en gradació ascendent climàtica: «e ab quanta dolor e amargor lo contemple ara veentlo així traücat e foradat, unflat e sangtrait!» (cap. 219: 450); el recurs constant al vocatiu, la forma del verb en imperatiu, el recurs al lèxic emfàtic, que remarca intensitat, amb l'ús d'isotopies o les repeticions contants d'unitats lèxiques, com ara: llàgrimes, congoixa, pietat, mort, plor, dolor i accions associades a aquestos termes, com sofrir, penar, perir ${ }^{18}$; expressions que en altres registres literaris es considerarien hipèrboles i en Villena, altrament, són visions que arriben a un gran nivell de clímax, en moments de tanta intensitat com és el fet de remarcar l'intens dolor de la Verge davant del cos mort del seu fill ${ }^{19}$. Cal esmentar la constant presència de la isotopia de termes associats a la contemplació, en diverses formes gramaticals («contemplació, contemplativa, contemplar», etc.) que s'afegeixen a adjectius emfàtics, com ara: «dolorosa, inflamada, dolça», etc. Amb aquestos recursos lingǘstics s'aconseguix, de fet, infondre sentiments d'afecte i de proximitat, al servei de la meditació, més enllà de tractar-se d'indicis d'una sensibilitat pretesament femenina.

I és que doctrina i didàctica es conjuminen a la Vita Christi mitjançant un estil retòric que presenta, a més, una alternança d'estils narratius: d'una banda, un estil que evidencia erudició teològica, amb al lusions freqüents als textos bíblics i patrístics, així com la recurrència a les expressions llatines en escenes en què es vol remarcar la solemnitat, en què sovint alternen dos plans: el real i el sobrenatural, on tenen cabuda la fantasia i l'al legoria, en una visió monàrquica del cel empiri (Fuster 1995; Ferrando 2015), on no són absents les danses i els besamans.

18 «Així, la mare dolorada, continuant son plant, convidà les virtuts a ella pus cares que vinguessen a plorar lo seu amat Fill, e deia...» (cap. 218: 447).

19 «Quina entrada tan dolorosa és aquesta, que lo meu cor és tot trencat dins mi mateixa e han tremolat tots los meus ossos per extrema pena?» (cap. 223: 457).

SCRIPTA, Revista internacional de literatura i cultura medieval i moderna, núm. 14 / desembre 2019 /pp. 205 - 228 ISSN: 2340-4841 · doi:10.7203/SCRIPTA.14.16366 


\section{Anna Isabel Peirats Navarro. La Vita Christi d'Isabel de Villena, misericòrdia restaurativa i profitosa doctrina al servei de la meditació}

En altres ocasions, s'evidencia al text de l'abadessa valenciana un estil realista, senzill, que traspua versemblança en l'ús dels detalls de la vida quotidiana, ${ }^{20}$ que permeten acostar al receptor una clara radiografia domèstica de les escenes que no podien conéixer a través de la lectura dels textos dels evangelis i que desprenen una clara funció emotiva, més que tractar-se d'un reflex de feminitat (Fuster 1995). Es tracta del recurs a l'ècfrasi (descripcions d'elements domèstics i quotidians), així com descripcions farcides de realisme, de quotidianitat, on es presenta la llengua en estil col loquial, amb l'ús de refranys, col loquialismes, amb una clara funció: acostar el text a les receptores des del contrast entre l'estil erudit i la senzillesa, per tal d'incitar la pietat i mostrar amb total afany de versemblança les escenes més íntimes de la vida de Jesucrist que no podien llegir-se en cap altre text. Parem esment, a tall d'exemple, a les viandes que santa Anna disposa per a la seua filla (la somera, el pa, els ous, el tronc perquè puga encendre foc a les muntanyes i, fins i tot, la civada per a la somera!) que ha d'emprendre el camí a Egipte; o com les donzelles, germanes de la Verge, despengen raïms i magranes, juntament amb altres fruits secs, viandes que la Verge agraeix amb profund amor filial abraçant $i$ besant la mà de la seua mare (cap. 83: 210-211).

Mitjançant un estil descriptiu sensitiu, que pinta amb paraules els fets més personals de la vida de Crist, en un món de ficció versemblant creat per l'abadessa, hi té especial cabuda l'ús dels diminutius, que en el vessant lingüístic, a més d'indicar tamany, expressen una sensació de tipus subjectiu o afectiu. Els diminutius s'empren, en la major part de les ocasions, quan es refereix als moments de la infància de Jesús («bolquerets», «cambreta», «talequeta»...) per tal de transmetre tendresa.

Aquest matís afectiu, mitjançant el qual llengua i estil són instruments de difusió d'una paraula encesa de devoció i d'adoctrinament, més enllà de reflectir un tarannà femení, o d'evidenciar la condició femenina de qui escriu l'obra ${ }^{21}$ contribueix més, si és possible encara, a commoure i a despertar emocions en les clarisses de la Trinitat, especialment en casos en què s'incideix en el caràcter maternal, amb què les receptores, pel fet de ser monges, es podien sentir més commogudes. Parem esment a diversos exemples: quan la Verge vol despertar sobtosament el seu fill i, en contemplar el seu rostre, queda trasbalsada de compassió, ${ }^{22}$ el goig de la mare, estant a Egipte, quan el fill

\footnotetext{
20 En aquest punt, tal com esmenta Fuster (1995: 54): «l'abadessa no empra de manera gratuita les expressions quotidianes, sinó que són premeditades, per tal d’impressionar la imaginació de les monges». Per a Fuster, Villena atorga versemblança a qualsevol relat evangèlic amb una tècnica de «reconstrucció novel lesca», en què tenen cabuda les escenes casolanes i la quotidianitat.
}

21 Fuster (1995: 69) remarca la importància de l'ús dels diminutius en Isabel de Villena en aquestos termes: «l'abundància de diminutius, que són la pura tendresa del llenguatge, sor Isabel els usa copiosament i amb un particular matís d'emoció, amb el to i l'oportunitat que solament podia donar-los una dona».

22 «E la senyora, dient aquestes coses, ab moltíssimes llàgrimes mirava lo Fill seu; e, veent que encara no es despertava, acostà's a ell ab molta amor e besà'l estretament per despertar-lo ab més dolçor, ab tot que lo dit Senyor, per lo trencament del son e per lo sobtós e cuitat despertament, se prengué a plorar ab una careta tant piadosa, que lo cor de la senyora mare sua fon així travessat d'extrema dolor que cuidà morir. E tornant-lo a besar ab molta compassió 


\section{Anna Isabel Peirats Navarro. La Vita Christi d'Isabel de Villena, misericòrdia restaurativa i profitosa doctrina al servei de la meditació}

pronuncia la seua primera paraula: «mare», que conforta l'ànima de la Verge (cap. 89: 221) i del pare, sant Josep, a qui el xiquet el mira fent-li «una rialleta» i dient «pare» (cap. 90: 222), o com plora la mare en saber que el fill s'ha perdut. ${ }^{23}$

Altres escenes que inspiren tendresa es refereixen al gest maternal de l'àvia Anna, que cus amb especial dedicació una camisa preciosa per al seu nét, a fi de celebrar el goig per la vinguda d'Egipte ${ }^{24}$; o el dolor de la Mare en morir el seu fill en la creu, en un impactant i extens plany, gens absent de retoricisme verbal, on es ressalta el dolor que sentia la Verge, a qui, en paraules de l'abadessa de la Trinitat, semblava que se li haguera esberlat el cor en «peces menudes» (cap. 186: 406).

\section{Misericòrdia restaurativa a la Vita Christi}

A la Vita Christi l'estil és un mitjà que fa servir l'abadessa per tal de presentar, a mode d'amplificació del discurs, un devocionari o, si més no, un manual en què la intenció doctrinal i didàctica (Escartí 2016) és l'objectiu de partida per tal de despertar emocions i devoció. Els eixos claus que fonamenten aquesta intencionalitat es concreten, en primer lloc, en l'ús particular del llenguatge retòric i, en segon lloc, com a conseqüència del poder connotatiu de la paraula, en un ideari de misericòrdia restaurativa.

Atés que la vida de Jesucrist que s'hi narra està adreçada a unes receptores femenines, on es remarca el protagonisme de les dones (Fuster 1995: 70), hom ha arribat a concloure que l'obra hauria pogut ser un al legat de la superioritat de la dona (Cantavella 2011), un exemple suprem de «literatura de gènere» (Twomey 2014: 22) on es reivindica la perspectiva femenina en la narració dels miracles de Jesús, obrats principalment en dones, o s’insisteix en l'especial tracte que Jesucrist els confereix, sobretot a Maria Magdalena.

De més a més, algunes afirmacions que pretenen recolzar aquesta pretesa «literatura de gènere», com ara que la forma de presentar la descripció del cos de la Mare de Déu mostra un coneixement més concret de la intencionalitat i de la naturalesa de la Vita Christi, atés que en la literatura medieval el cos de la dona era considerat com a imperfecte (Twomey 2014: 44), no responen més que a la mateixa idea apuntada pels teòlegs i sermonadors anteriors sobre l'immaculisme de la Mare de Déu;

prenguél al braç, afalagant-lo ab molta amor, e deia-li: Ai, vida mia! E no ploreu, car vós sabeu ab quanta dolor vos he jo despertat per la gran temor que tinc del perill vostre, car só certa, Senyor, que los enemics vostres no dormen ne cessen de perseguir a vós» (cap. 82: 208).

23 «E Josep, que oí una tan dolorosa nova que perdut haguessen lo Fill de Déu, a ell tan carament acomanat, cuidà morir, llançant tan grans crits e plors que tots los mirants movia a molta pietat. E la dolor de la senyora e del dit Josep era tanta, que la u no podia consolar l'altre» (cap. 95: 228).

24 «E la dita senyora Anna presentà al seu amat nét una camisa que li havia feta per goig de la venguda, ab freset d'or en les mànegues e en los muscles, la qual lo Senyor vestia ab molt plaer per amor de la santa àvia sua» (cap. 95: 227). 
així, doncs, la visió immaculada del cos de la Verge a la Vita Christi no presenta a les lectores l'opció de percebre el seu propi cos com a més sagrat del que es considerava en el moment (Twomey 2014: 49), o que el plor i l'emotiu dolor de la Verge demostre que en la contemplació, que, d'altra banda és una experiència mística i espiritual, intervenen tant el cos femení com l'esperit (Twomey 2014: 51).

Nogensmenys, Isabel de Villena no centra el seu dictum narratiu a mostrar la superioritat femenina, sinó que pretén instruir en uns models femenins dignes i virtuosos. Si són les monges les primeres receptores de l'obra, hauran d'interioritzar que són les destinatàries escollides. L'opció de Villena té una finalitat clara, doncs, que no és el profeminisme, sinó la incitació a meditar, a partir de la dignitat cristiana, al voltant del perdó atorgat als personatges bíblics més marcats en l'Antic i en el Nou Testament, pel fet d'haver comés errors o, altrament, el reconeixement just als personatges que mereixen un lloc preeminent al cel pel fet de reeixir en l'exercici de les virtuts. En aquest sentit, la lectura que es desprén és que és possible una justícia o misericòrdia restaurativa, tot $\mathrm{i}$ haver incorregut en faltes greus, tant per part d'exemples masculins com femenins, si bé es recorre amb més insistència a les imatges femenines, que són les que més s’han menystingut en la tradició bíblica i patrística; i perquè, és clar, dones són també les receptores primeres de l'obra. Així, doncs, assistim a un procés de restauració moral de les dones (Alemany 2012: 328), especialment d'Eva i de Maria Magdalena, expressat mitjançant un discurs filogin.

Les dones escollides, juntament amb la dona per excel lència, la Verge Maria, són virtuoses i constitueixen a la Vita Christi un exemplum ad imitandum, model o referent de conducta al qual han d'aspirar les monges per tal d'assolir la gràcia de la salvació. En aquesta línia, la filogínia a la Vita Christi està al servei d'una clara intenció didàctica, per tal que les monges se senten protagonistes i part imprescindible de la salvació.

El pont de transició per a arribar a una vida assegurada en el més enllà és la meditació, i el mitjà apologètic que empra l'abadessa com a arma de persuasió és la paraula emotiva, encesa, més que una prosa tenyida de connotacions feministes. I és que a la Vita Christi existeix la misericòrida restaurativa i el perdó, no sols per a les dones pecadores (Eva, Maria Magdalena, la dona samaritana...), sinó també per als hòmens (Adam, Josep, Joaquim, o el lladre Dimas), que ara són redimits.

En primer lloc, la donzella Misericòrdia s’adreça a la Verge com «aquella que la clemència divina ha promés a l'hom per reparació i delit seu» (cap. 26: 115); amb la Mare de Déu s'uneixen els àmbits humà i diví per misericòrdia divina, per tal de reparar les faltes comeses, per la qual cosa és «mare de misericòrdia» $\mathrm{i}$ «metgessa de natura humana» (cap. 45: 141), capaç de curar les malalties del món, ja que l'abadessa la considera com a espill i regla de virtuts (cap. 45: 142). La Verge pot atorgar el perdó a la mare Eva, que prega amb fervor i mostra agraïment mitjançant un besamans reial, com a conseqüència del triomf de la gràcia de la misericòrdia (cap. 45: 168). 


\title{
Anna Isabel Peirats Navarro. La Vita Christi d'Isabel de Villena, misericòrdia restaurativa i profitosa doctrina al servei de la meditació
}

La figura d'Eva, tan castigada en la tradició patrística, per autors com el mateix Tertul liàa és ara una dona virtuosa, atés que mostra un sincer penediment pel fet d'haver desobeït Déu, i demana pietat, en primer lloc, a Adam. A la Vita Christi se supera amb escreix la maledicció imposada a Eva per tota la humanitat, per la qual cosa ara és redimida, des de la dignitat cristiana:

\begin{abstract}
E per ço Adam, senyor, puix vós, per lo mal consell meu fes aquella tan gran erra de desobeir nostre senyor Déu e trencar lo manament seu, plàcia-us ara per mercé escoltar la dolorosa paraula mia, qui contínuament pense e fabrique en la reparació vostra e mia e dels fills meus [...] car jo per ma desaventura, no he trencat lo cap al diable, ans ell ha vençut a mi e llançat tota la generació mia en la captivitat dolorosa que ara som. (cap. 10: 81-82)
\end{abstract}

Santa Anna, mare virtuosa de la Verge, dona de «virtuosa vida» (cap. 80: 202) compassiva i exemple de virtuts, teologals, a més de pobresa i obediència, pietat i humilitat, pròpia del franciscanisme (Ramon 2015: 106), per a totes les vídues i verges, sobretot per «a aquelles qui en col legis de religió viuran», constitueix un model a imitar per les monges, per tal com ha interioritzat la certesa que els pecats comesos li seran perdonats per la clemència del seu nét:

\begin{abstract}
E restà la virtuosa viuda d'aquest raonament així aconsolada e contenta que li paria ja posseir paradís, puix la senyora reina d'aquell li donava seguretat de la salvació sua dient-li certament ésser-li perdonats tots los seus pecats per lo senyor Fill seu, qui era ver redemptor e perdonador de pecats per sa sola clemència. (cap. 80: 202)
\end{abstract}

Una figura femenina que esdevé un model a imitar a la Vita Christi és, en particular, Maria Magdalena ${ }^{26}$, a qui es dediquen els capítols 117 a 121, a més de les nombroses referències que es troben al llarg de tota l'obra. A diferència del que es repeteix en molts dels sermons medievals, l'abadessa considera que Magdalena, a qui res no li era difícil aconseguir, per les seues riqueses, no tenia «negun reprenedor» (cap. 117: 258), és a dir, seguia els apetits de la carn perquè ningú li ensenyava un model recte de vida. I coincidint Maria Magdalena en una de les predicacions de Jesucrist, a la Vita Christi es narra com Crist la va mirar amb ulls de clemència $i$ li va infondre una sageta d'amor espiritual:

\footnotetext{
25 Una de les màximes de denigració que es fan presents en Tertul lià és la identificació del gènere femení amb la mateixa Eva: «Et Evam te esse nescis? Vivit sententia Dei super sexum istum, in hoc saeculo: vivat et reatus necesse est. Tu es diaboli janua, tu es arboris illius resignatrix, tu es divinae legis prima desertrix, tu es quae eum persuasisti» (De cultu feminarum, PL 1, 1305).

26 Vegeu Pere Comestor, Historia scholastica (PL 198, 1615). En la Vita Christi d'Isabel de Villena, es deixa constància de la conversió de Maria Magdalena a la fe —motiu 3196 en Tubach: «Conversion of Mary Magdalene». En el capítol II de la jornada II de la Quarentena de contemplació, Eiximeno (1986: 66) introdueix l'exemple de Maria Magdalena, que va abandonar les tenebres del pecat i es va armar de les armes de la llum de la penitència, pel fet de prostrar-se als peus de Jesús i penedir-se dels pecats comesos.
} 


\title{
Anna Isabel Peirats Navarro. La Vita Christi d'Isabel de Villena, misericòrdia restaurativa i profitosa doctrina al servei de la meditació
}

E venint sa majestat per preïcar e pujant en lo predicatori, mirà de fit la dita magdalena ab aquells ulls de clemència, tirant-li una sageta d'amor dins lo seu cor, la qual, sentint-se així nafrada i tirada estava tota alterada, mudant los seus pensaments (cap. 117: 259).

En aquest mateix passatge, en què s'insisteix en el fet que Crist ha vingut a reconciliar pecadors i a infondre pau entre Déu i la humanitat, Magdalena es llança als peus de Jesucrist i els ungeix amb ungüent, com a preludi de la resurrecció de Crist, alhora que demana misericòrdia (cap. 119: 264). La humilitat, la caritat i la fe de Maria Magdalena són atributs que la converteixen en un exemple de dona penitent (Recio 2002). ${ }^{27}$

Un altre exemple de dona virtuosa que cal esmentar a la Vita Christi és el de la samaritana, que demana aigua prop de Sicar $(J n$ 4, 9) i es mostra perplexa pel fet que Jesús, que és jueu, demana aigua a ella, que és samaritana. I Jesús li ofereix una aigua de la qual ja no tindrà més set, referint-se a l'aigua de la salvació eterna ${ }^{28}$. Amb aquest exemple, es presenta a la Vita Christi un enfocament centrat en el fet d'identificar la dona samaritana amb la resta del gènere femení, a qui Jesucrist vol anunciar la seua paraula; és a dir, Crist vol difondre el seu missatge de salvació de manera directa a les dones, i per això s'adreça en primera persona a la samaritana, que, gens avara i molt caritativa, anunciarà l'evangeli a tota la gent:

\footnotetext{
jo et vull donar aquell gran tresor amagat de la gràcia mia e comunicar a tu lo secret tan amagat de la redempció humana, e que conegues e veges per experiència certa que jo só lo Senyor e ver Messies que tant desitges. Vet-me ací que parle ab tu, comunicant-te qui só ne a què só vengut, car tu est ací en persona de totes les dones, a les quals jo vull donar aquesta glòria singular. (cap. 124: 276)
}

\begin{abstract}
27 Aquesta figura de Maria Magdalena, que tots els predicadors medievals, i també la Vita Christi identifiquen amb Maria de Betània, constitueix un exemple a imitar, per la qual cosa va tindre especial rellevància a l'Edat Mitjana, sobretot entre els semonadors europeus (Ferreiro 2010; Jansen 2000), com a exemple de dona penitent: el dominicà Giordano da Pisa la identifica amb la dona a qui Crist va expulsar els set dimonis (1989, predica 36); Bernardí da Siena (1989, predica 23) remarca el perdó de Crist i el fet de llavar els seus peus amb llàgrimes de penediment; sant Vicent Ferrer remarca en Maria Magdalena l'exemple de dona que es penedeix dels seus pecats, per tal com primer anava amb el cap alt i després el va abaixar quan es va convertir (Sanchis 1934: II, 192), amb la qual cosa esdevé un exemple de dona penitent (Garganta 1980; Ferreiro 2010). Un dels aspectes que tots els predicadors remarquen després de la conversió de Maria Magdalena, seguint la font de la Legenda Aurea (2007: 713), és la inclinació a la predicació, el model missioner i l'exercici de la vida contemplativa, atés que la santa va estar 33 anys, els mateixos que tenia Jesús quan va morir, sense menjar pa ni beure vi ni aigua, dedicada a la contemplació set hores al dia, després de les quals acudien els àngels i la sustentaven.
\end{abstract}

28 Aquesta dona virtuosa és motiu de comentari en els textos dels predicadors, com és el cas de sant Vicent Ferrer (Sanchis Sivera 1929: 160) que interpreta el passatge en clau al legòrica, en què el pou és la ciència de Déu, la samaritana representa la filosofia, per tal com Jesucrist vol convertir persones infidels a la veritat de la fe cristiana. A més, i en l'Spill de Jaume Roig s'aprofita el passatge bíblic per mostrar un dels defectes de les dones, de revelar secrets ocults (vv. 7873-7888). 


\title{
Anna Isabel Peirats Navarro. La Vita Christi d'Isabel de Villena, misericòrdia restaurativa i profitosa doctrina al servei de la meditació
}

Pel que fa a les figures masculines que envolten la vida de Jesucrist, en primer lloc cal destacar Adam, que es veu exiliat en el món de les tenebres per la falta comesa en desobeir Déu (cap. 10: 81); ara, però, és perdonat i redimit. La Verge, que és artífex de reconciliació de Déu amb la humanitat i una «font gloriosa de misericòrdia» (cap. 8) sent compassió per Adam i per la seua dissort i demana clemència al seu Fill. És així com Déu pot actuar des de la misericòrdia divina i restaurar la dignitat, que implica el canvi de l'infern al cel empiri: ${ }^{29}$

\begin{abstract}
Per ell e sos fills nunca se són millorats de res, ans s'estan en la dita terra pobres e freturosos de la gràcia divina e, morint Adam, la millor cortesia que ha pogut haver és estada que l'han mès en casa fosca, e aquí es troba hui, ab los millors de sos fills, cridant e suplicant a vostra mercé vulla pregar la clemència divina per ells, que els haja mercé. E la senyora, havent molta compassió del desaventurat cas d'Adam, alçà los ulls al cel. (cap. 6: 69)
\end{abstract}

Joaquim, que era «no conegut ni estimat, ans llançat e menyspreat com a home infructuós» (cap 1: 53) constitueix un exemple de marit virtuós (cap. 2). Josep és un exemple d'obediència i de castedat (cap. 10), que demana clemència divina a través de l'oració, per tal d'entendre l'objectiu del misteri de l'encarnació del Fill de Déu en les entranyes de la seua esposa, amb la qual cosa esdevé un model a imitar, perquè recorre a demanar misericòrdia per tal d'obeir la voluntat de Déu. Josep, que havia contemplat l'opció de deixar l'esposa, ara se sent penedit, amb la qual cosa infon misericòrdia també en la seua esposa ${ }^{30}$, que el perdona de bon grat.

En el passatge en què sant Josep i la Verge arriben a una cova de lladres es fa prevaldre també la clemència divina, que permet la mutació dels lladres, de tindre «cors lleonencs»a infondre dolçor i pietat, no sols en el capità dels lladres, sinó també en la seua esposa, que en escoltar les paraules del seu marit, besa les mans de la Verge, alhora que demana pietat perquè cure el seu fill (cap. 86). La Verge actua amb misericòrdia i demana clemència a Crist, mitjançant una imprecació en què mostra haver rebut un secret diví: la misericòrdia i el perdó per a la mare, en senyal d'agraïment per l'acollida que els han oferit a la cova i la curació del fill malalt, que serà Dimas. Aquest fill de lladres seguirà les males inclinacions del seu pare, robarà i serà perseguit, serà pres i crucificat al costat de Jesús i es convertirà a la fe divina, fins i tot en els moments en què els deixebles de Crist s'apartaran del mestre; amb aquest fet, de la conversió del lladre Dimas, es mostrarà de nou l'aplicació de la misericòrdia divina. ${ }^{31}$

29 «Lo Senyor que ha donat a l'home sentència de mort per lo pecat seu, ell mateix lo pot reduir a vida, per sola clemència sua; $e$ aquell qui és devallat fins a les portes d'infern, ço és en los llimbs, on ara es troba Adam, d'aquí pot ésser rellevat per la divinal potència, e pujat en aquell lloc on és tot repòs» (cap. 15: 93).

30 «E la Senyora clement, havent molta compassió del sant vell, anà cuitadament a ell e, ab los ulls plens de llàgrimes, llevà'l de terra, dient que ella li perdonava de molt bona voluntat e que havia passada molta congoixa de la sua dolor, e que s'alegràs, puix nostre Senyor l'havia tant aconsolat revelant-li lo secret misteri de la incarnació» (cap. 43: 175).

31 «Ocuparà la vida sua en grans lladronicis en homeis, e, en aquells perseverant llargament serà pres en lo temps

SCRIPTA, Revista internacional de literatura i cultura medieval i moderna, núm. 14 / desembre 2019 /pp. 205 - 228 ISSN: 2340-4841 · doi:10.7203/SCRIPTA.14.16366 


\section{Anna Isabel Peirats Navarro. La Vita Christi d'Isabel de Villena, misericòrdia restaurativa i profitosa doctrina al servei de la meditació}

Altres personatges masculins que cal esmentar són: sant Pere, que després de la mort de Crist acudeix, desconsolat, al cenacle «aterrat per vergonya e confusió» (cap. 228: 465) de l'errada comesa pel fet d'haver negat Crist. El penediment i el dolor són necessaris per tal de moure la pietat de la Mare de Déu, en aquest cas, com a dispensadora de la clemència divina, que perdona el cor adolorit de sant Pere, que plora amb contricció i agraeix la misericòrdia de la Mare (cap. 229: 468).

I en la glòria del cel després de l'Ascensió de Crist, s'estableix una jerarquia d'ordes celestials, que s'argumenta d'acord amb la clemència i la justícia divina, amb especial èmfasi en aquelles persones que han entregat la vida per Déu, que han sigut obedients, o exemples de penitents, tant masculins com femenins. En aquesta visió estratificada del cel se situen en bon lloc, en l'orde dels serafins, els primers pares, Adam, a qui correspon la primera cadira i Eva, asseguda al seu costat (cap. 260: 519). En el mateix orde se situarà sant Josep, amb santa Anna; en l'orde dels querubins s'asseuran els hòmens de ciència, com ara Joan el Baptista, Isaïes, Ezequiel i Daniel (cap. 261); en els trons figuraran els patriarques, com Abraham, Jacob i Melquisedec (cap. 262), mentres que en les dominacions s'asseuran Abel, primer màrtir, que va morir víctima de l'enveja del seu germà, per la qual cosa mereix la clemència divina, així com els sants innocents, que van vessar la seua sang en nom de Crist i mereixen estar situats en aquest orde celestial, en reparació a la seua vida, i la mare dels Macabeus, que va renunciar a la pròpia vida i va entregar els seus fills al martiri (cap. 263: 522).

En l'orde dels principats Déu situa les persones devotes i obedients, que mereixen el triomf, com és el cas de Moisés, els sacerdots Aaron, Simeó i Zacaries, i els capitans de religions, Samuel i Eliseu (cap. 264). Els vells Elies i Enoc, que aturaran el poder de l'Anticrist, el rei David, que va véncer el gegant Goliat que atemoria tot un poble, i les dones virtuoses Judit ${ }^{32}$ i Ester ocuparan l'orde de les potestats (cap. 265: 524): Judit pel seu valor i fortalesa, que va matar el seu marit Holofernes, perseguidor dels cristians; Ester, perquè va saber apaivagar la supèrbia d'Aman.

En aquest cel tan pictòricament descrit trobem a l'orde de les virtuts (cap. 266: 526) Jossies, perseguidor dels falsos ídols; Josué, que a la mort de Moisés va regir el poble d'Israel, i la profetessa Dèlbora $^{33}$, que va regir de manera justa i durant quaranta anys el poble d'Israel. En l'orde dels arcàngels (cap. 267: 527) figuren Jeremies, que es lamentava durant tota la seua vida per la destrucció de Jerusalem; Josep, fill de Jacob que, tot $\mathrm{i}$ haver sigut venut pels seus germans, no se'n va venjar,

dolorós que el meu Fill serà cruelment perseguit e mort, e finarà la vida al costat seu. Aquest se convertirà a l'amor e coneixença del dit senyor Fill meu, ab tanta força de fe que, ab tot lo veurà en pena e turment e en molta humiliació, lo confessarà rei e Senyor e donador de glòria quan los jueus e majors de la llei lo maleiran e menysprearan. Aquest tendrà la fe ferma quan los criats i deixebles del Fill meu la perdran. En aquest contemplaran llargament los pecadors la granea e immensitat de la misericòrdia divina» (cap. 86: 218).

32 Judit també és considerada com a dona virtuosa a l'Spill (v. 12804) i a l'Speculum Humanae Salvationis, c. 30 a i correspon al motiu 2593 en l'índex de Tubach.

33 La característica de dona virtuosa de Dèbora es fa constar també a l'Spill de Jaume Roig (vv. 15223 i ss.) en el discurs en què el savi Salamó presenta tot un seguit de virtuts femenines com a exemple a imitar per les dones.

SCRIPTA, Revista internacional de literatura i cultura medieval i moderna, núm. 14 / desembre 2019 /pp. 205 - 228 ISSN: 2340-4841 ·doi:10.7203/SCRIPTA.14.16366 
sinó que els va compensar pel mal comés; Tobies, per complir les obres de misericòrdia amb el proïsme, i Abigail ${ }^{34}$, la prudència de la qual va evitar la mort del seu marit David, a qui va servir sempre.

L'orde dels àngels custodis (cap. 268: 529), en darrer terme, està destinat a Job, exemple de paciència; Mataties, que va entregar la vida pel seu poble; Calef, deixeble que mai no va desconfiar de Moisés, i la profetessa Anna, que trobant-se viuda va entregar la vida a l'exercici de les obres caritatives, per la qual cosa mereix l'honor i el reconeixement de ser situada en aquest orde.

Amb aquesta subdivisió argumentada d'acord amb els guardons que mereixen justament els personatges de l'Antic i del Nou Testament que han sigut màrtirs, han preservat la llei de Déu o han pecat i s'han penedit amb autèntica contricció, la conclusió que s'hi fa palesa és que, en efecte, el pecat existeix, però el penediment, la meditació i l'oració són el mitjà indispensable perquè prevalga la misericòrdia restaurativa. Des de l'òptica de la dignitat cristiana, la lectura és clara: Déu no condemna, no és un Déu que castiga, sinó un Pare que perdona.

Amb tot, l'objectiu doctrinal i moralitzant és més que directe, $\mathrm{i}$ aporta garantia de salvació espiritual a qui llija la Vita Christi i actue fent prevaldre les virtuts, sobretot femenines, que han de ser el model a seguir per les monges. Entre aquests models, la Verge excel leix, però no es presenta des de l'òptica de la misogínia com a únic model en detriment de totes les dones, sinó que esdevé un símbol (Fuster 1995) de tot el gènere femení.

Les dones, que segueixen el símbol de la vida contemplativa que representa Maria, es veuran reflectides en la tendresa maternal, en la penitència (de xicoteta s'abstenia de mamar alguns dies de la setmana, per tal com el dejuni era salut de l'ànima, cap. 4: 61), en l'exercici de l'oració continuada (cap. 4), es commouran amb el dolor...En cada escena de la vida de Crist, que Isabel de Villena ja selecciona al servei d'aquest objectiu, de servir de model a les receptores, hi ha dones: cinc dones són la representació al legòrica de les donzelles enviades per Déu per a servir la Verge: benignitat, pobretat, prudència, paciència $i$ fermetat (cap. 3). Jesucrist obrarà miracles en ressuscitar una donzella, filla del príncep de la sinagoga (cap. 115), com a resultat de la fe mostrada pel seu pare; en el mateix passatge cura la malaltia greu d'una dona ferventíssima que havia despés grans quantitats de diners en metges i es cura de la seua malaltia només en tocar la túnica de Jesucrist. També cura la filla de la dona cananea, que destaca per la seua fermesa i paciència i demana a Crist que la mire «ab ulls de clemència» (cap. 125: 277), amb la qual cosa s'opera el miracle diví, després d’haver imprecat misericòrdia a Crist amb fe $\mathrm{f}^{35} \mathrm{i}$ d'haver fet oració.

34En les virtuts d'Abigail (1 Sa 25, 23) insisteix també l'Spill de Jaume Roig, i constitueix una figura de la Mare de Déu, tal com es documenta al cap. 37 b de l'Speculum Humanae Salvationis.

35 Aquest mateix exemple de la dona virtuosa cananea és motiu d'un comentari en un dels sermons de sant Vicent Ferrer (Sanchis Sivera 1929: 86) com a model de fe i confiança en la clemència divina. 


\title{
Anna Isabel Peirats Navarro. La Vita Christi d'Isabel de Villena, misericòrdia restaurativa i profitosa doctrina al servei de la meditació
}

Jesucrist s'apareix, en ressuscitar, a Maria Magdalena, que es troba desconsolada front al sepulcre buit; disfressat amb hàbit, Jesús fa una reverència a Magdalena, que el confon amb un hortolà (cap. 242: 490) fins que el reconeix en pronunciar el seu nom i anunciar que no dubte, perquè la clemència del Senyor no permet desamar a ningú que li mostre afecció. Aquesta visió es completa amb la posterior aparició de Crist a les altres dones ${ }^{36}$ que acompanyen Maria Magdalena, com un privilegi que elimina dràsticament la maledicció d'Eva, amb la salutació «avete»:

\begin{abstract}
e prengueren los peus e mans de sa clemència, e ab infinit goig besaren-los moltes vegades, essent molt certes de la resurrectió sua. Primo mulieres merentur audire aucte, ut maledictum Eve mulieris in mulieribus solveretur. No sens gran misteri primerament han meritat les dones oir la tal salutació, ço és: Avete, mostrant lo Senyor clarament que la maledictió donada a la primera dona, qui fon Eva, era ja, del tot, de les dones apartada. (cap. 243: 492)
\end{abstract}

\section{Conclusions}

Amb tot, es pot afirmar, a tall de cloenda, que la Vita Christi no és una resposta profeminista a l'Spill de Jaume Roig, atés que els dos textos presenten una matèria narrativa molt diferent, a més del fet que Isabel de Villena no presenta arguments a contrario de l'obra del metge valencià, ni explícitament, com era habitual en les obres del corrent profeminista, a l'estil de Cristine de Pizan, ni de manera implícita, quant a contingut ni forma. La Vita Christi no pretén mostrar la superioritat ni major dignitat de les dones respecte del gènere masculí, que és la tesi que es defensa des del vessant profeminista, sinó que pertany a un altre corrent espiritual i literari, un ars meditandi, d'inspiració en les Meditationes Vitae Cristi i en el fransciscanisme, que parteix del clar propòsit didàctic i catequètic d'incitar a la meditació, per tal de commoure mitjançant l'afecte i l'emotivitat.

A aquesta doble finalitat, didàctica i moralitzant, s'afegeix el fet particular que les receptores del text, a diferència del corrent de les obres immerses en l'ars meditandi, són les dones, les monges clarisses del convent de la Trinitat, per la qual cosa són les destinatàries primeres, escollides, per a ser protagonistes de la Redempció de Crist. Al servei d'aquesta intencionalitat, centrada a commoure les receptores de l'obra, es justifica el fet que Isabel de Villena seleccione i mostre predilecció per aquelles escenes en què apareixen dones virtuoses de l'Antic i del Nou Testament, com és el cas de la dona samaritana, la dona cananea i Maria Magdalena, entre d'altres, com a exemples de vida i de conducta a imitar per les monges, a més d'aquelles escenes en què es remarca la maternitat de la Mare de Déu o de l'àvia de Jesucrist, santa Anna, que busquen despertar tendresa i emoció.

Al servei del propòsit de moure els afectes a través dels sentiments i de la meditació, de la mateixa manera que les obres del corrent espiritual de la devotio moderna, l'opció per la llengua i l'estil a la Vita Christi, d'influència en el franciscanisme, és un mitjà que empra l'abadessa valenciana per

36 Aquesta aparició de Crist a les dones es contemplava en l'Spill de Jaume Roig en el sentit de mostrar que Jesucrist coneixia la capacitat de les dones de fer públic qualsevol fet, per més compromés que fóra: «a dones, clar,/se volc mostrar,/enans del dia./Car bé sabia/tost correrien /i ho preycarien,/res no tement» (vv. 7865-7871). 


\section{Anna Isabel Peirats Navarro. La Vita Christi d'Isabel de Villena, misericòrdia restaurativa i profitosa doctrina al servei de la meditació}

a despertar la imaginació, des de la tècnica freqüent de l'al legoria; a més, s'uneix el recurs a fer prevaldre la fantasia, que permet entendre el cel com una cort en què abunden els besamans reials, o commoure els afectes de les monges amb el to senzill en què es narren, a mode d'amplificació del discurs, com a tècnica pictòrica o cinematogràfica, fins i tot els mínims detalls que envolten la vida quotidiana de Jesucrist. La imaginació d'Isabel de Villena permet al lector viatjar des dels llimbs, on es troben els primers pares, a més dels patriarques, fins al cel empiri, que presenta una gràfica estructura, argumentada d'acord amb els mèrits obtinguts com a conseqüència d'una vida virtuosa.

En tots els ordes celestials hi ha lloc per a les dones, de les quals es lloen les vides virtuoses, de la mateixa manera que ho havien fet Eiximenis, els predicadors com sant Vicent Ferrer, o el mateix Jaume Roig a l'Spill. A la Vita Christi, però, no tan sols es fa especial menció de les dones i dels hòmens virtuosos de l'Antic i del Nou Testament, sinó també de les dones i dels hòmens que havien sigut castigats pels errors comesos, com els mateixos Adam i Eva o el lladre Dimas, entre d'altres, i que ara són redimits des de la misericòrdia restaurativa, com a exemple de la dignitat cristiana i de la clemència divina. Aquesta restauració moral permetrà a les monges receptores identificar-se amb aquestos personatges que, bé des dels actes virtuosos, bé des de la contricció i del penediment autèntics, són elegits per Déu per a habitar a la cort celestial.

La misericòrdia divina, doncs, permet igualar els mèrits als sers virtuosos $\mathrm{i}$ als penitents, on no hi ha cabuda per als feminismes ni per a mostrar la superioritat de les dones respecte dels hòmens; és per això que Isabel de Villena ofereix, des del plaer estètic i des del to emotiu, una obra didàctica i moralitzant, amb la intenció que servira a les monges com a profitosa doctrina. 
Anna Isabel Peirats Navarro. La Vita Christi d'Isabel de Villena, misericòrdia restaurativa i profitosa doctrina al servei de la meditació

\section{Bibliografia}

Alemany, R. (1993) «Dels límits dels feminisme d'Isabel de Villena», Actes del Novè Col loqui Internacional de Llengua i Literatura Catalanes, Barcelona, Publicacions de l'Abadia de Montserrat, pp. 301-313, vol. I.

—_. (2012) «Una visión filógina de Eva y María Magdalena», Cultura Neolatina, 72, pp. 325-349.

Arronis, C. (2015) La vida de la sacratíssima verge Maria, de Miquel Peres (1494), Barcelona, Institut Interuniversitari de Filologia Valenciana / Publicacions de l'Abadia de Montserrat.

Bernardino de Siena, Sant (1989) Prediche volgari sul campo di Siena, 1427 (Delcorno, C. ed.), Milano, Rusconi, 2 vol.

Bodenstedt, M.I. (1944) The Vita Christi of Ludolphus the Carthusian, Washington, The Catholic University of America.

Broad, J./Green, K. (2009) «Christine de Pizan», A History of Women's Political Thought in Europe, 14001700, Cambridge, Cambridge University Press, pp. 10-37, doi10.1017/CBO9780511576089.003

Cantavella, R. (1987) Protagonistes femenins de la Vita Christi, Barcelona, La Sal. Edicions de les dones.

- (2005) «Isabel de Villena (1430-1490)», dins Font, P. (ed.) Deu dones i el cristianisme, Barcelona, Cruilla / Fundació Joan Maragall, pp. 139-155.

- (2011) «Intellectual, Contemplative, Administrator: Isabel de Villena and the Vindication of Women», dins De Ros, X./ Hazbun, G. (eds.) A Companion to Spanish Women's Studies, Woodbridge, Tamesis, pp. 97-107.

_- (2013) «El denominat "estil afectiu” en la Vita Christi d'Isabel de Villena. Notes d'exegesi isabelina», dins Colón, G. (ed.) Els escriptors valencians del segle xv, Castelló de la Plana, Universitat Jaume I, pp. 193-233.

Cátedra, P. (1994) «Introducción a Enrique de Villena», dins Cátedra, P. (ed.) Obras completas, Madrid, Turner, vol. I.

Da Pisa, G. (1974) Quaresimale fiorentino 1305-1306 (Delcorno, C. ed.), Firenze, G.C. Sansoni, Coll. Autori Classici e Documenti di lingua Pubblicati dall'Accademia della Crusca.

Eiximeno, J. (1986) Quarantena de Contemplació (Hauf, A. ed.), Barcelona, Publicacions de l'Abadia de Montserrat.

Escartí, V. J. (2011) «L'obra literària d'Isabel de Villena», estudi introductori a Isabel de Villena, Vita Christi, València, Institució Alfons el Magnànim, pp. 15-42.

_. (2016) «Sobre la voluntad didáctica en la obra de sor Isabel de Villena», Mirabilia, 22, pp. $57-76$.

Ferrando, A. (2015) «Llengua i espiritualitat en la Vita Christi d'Isabel de Villena», Scripta, Revista internacional de literatura $i$ cultura medieval $i$ moderna, 6, pp. 24-59, doi:10.7203/SCRIPTA.6.7838 
Ferreiro, A. (2010) «St. Vicent Ferrer's catalan sermon on s. Mary Magdalene», Anuario de Estudios Medievales (AEM), 40/1, pp. 415-433.

Fonte, M. (1988) Il merito delle donne (Chemello, A. ed.), Venècia, Mirano Editrice Eidos.

Furió, J. M. (2015) Lo Terç del Cartoixà de Joan Roís de Corella. Estudi i edició. Tesi doctoral, València, Universitat de València.

Fuster, J. (1995) Missògins i enamorats (Hauf, A., ed.), Alzira, Bromera.

Garcia Peris, V. (2015) La traducció corellana de la Vita Christi de Ludolf de Saxònia. Edició crítica i estudi traductològic del llibre Primer', València, 1496. Tesi doctoral, València, Universitat de València.

García-Villoslada, R. (1956) «Rasgos característicos de la devotio moderna», Manresa, 28, pp. 315-358.

Hauf, A. (1979) «El ars praedicandi de fra Alfonso de Alprão, OFM. Aportación al estudio de la teoría de la predicación en la Península Ibérica», $A F H, 72$, pp. 233-329.

—_. (1990) D'Eiximenis a sor Isabel de Villena. Aportació a l'estudi de la nostra cultura medieval, València/ Barcelona, Institut de Filologia Valenciana/Publicacions de l'Abadia de Montserrat.

—. (2006) «La Vita Christi de sor Isabel de Villena (s. xv) como arte de meditar. Introducción a una lectura contextualizada», València, Biblioteca Valenciana.

Hyma, A. (1925) The Christian Renaissance. A History of the Devotio moderna, New York, Century.

Garganta, J. M. (1980) «San Vicente ferrer, predicador de penitencia y de reforma», Agiografia dell'Occidente Cristiano secol XII-XV, Roma, pp. 129-165.

Jansen, K.L. (2000) The making of the Magdalen: preaching and popular devotion in the later Middle Ages, Princeton.

Marinella, L. (1595) Colomba sacra. Venezia, Gio. Battista Ciotti.

- (1597) Vita del serafico et glorioso S. Francesco, descritta in ottava rima. Con un discorso del rivolgimento amoroso verso la somma bellezza, Venezia, Bertano.

- (1601) La nobiltà et l'eccellenza delle donne, co'diffetti et mancamenti degli huomini, Venezia, Gio. Battista Ciotti.

—. (1602) Vita di Maria Vergine imperatrice dell'universo, Venècia, Barezi e Compagni.

Martorell, J. (2003) Tirant lo Blanch (Hauf, A. ed.), València, Tirant lo Blanch.

Merino, J.A. (1982) Humanismo franciscano: Franciscanismo y mundo actual, Madrid, Cristiandad.

Narbona, M. (2009) «Noblas donas: las mujeres nobles en la casa de María de Castilla, reina de Aragón», Studium. Revista de Humanidades, 15, pp. 89-113.

Orts, J.Ll. (1991) «A propòsit de l'estil femení en sor Isabel de Villena», Actes del IX Col loqui Internacional de Llengua i Literatura Catalanes, Barcelona, Publicacions de l'Abadia de Montserrat, pp. 315-326. 
Anna Isabel Peirats Navarro. La Vita Christi d'Isabel de Villena, misericòrdia restaurativa i profitosa doctrina al servei de la meditació

Oviedo, J. (2017) El segon del Cartoixà de Joan Roís de Corella (1500). Edició i estudi. Tesi doctoral, Alacant, Universitat d'Alacant.

Passi, G. (1599) I donneschi diffetti, Venezia, Iacomo Antonio Somasco.

Patrologiae Cursus Completus Series Latina (PL) (Migne, P. ed. 1841-1855), 217 vol. Disponible en http://www.documentacatholicaomnia.eu/

Peirats, A. I. (2003) «Jaume Roig: la comicitat de la moral o la moral de la comicitat?», Estudis Romànics, 25, pp. 251-278.

(2019) «Chi disse donna, volse dir danno? La respuesta de Lucrezia Marinella (1601) al tratado de Giuseppe Passi (1599) sobre los defectos de las mujeres», Romanistische Zeitschrift für Literaturgeschichte, 43, pp. 135-167.

Pizan, Ch. de (1986) Le livre de la cité des Dames (Hicks, E./Moreau, T. eds.), París, Stock.

Ramon, Ll. (2015) «El modelo hagiográfico de santa Ana en la valencia tardomedieval», Medievalia 18, 2, pp. 97-117.

Recio, R. (2002) Mary Magdalene in Medieval Catalan Literature, dins McInnis, J. (ed.) Models in Medieval Iberian Literature and Their Modern Reflections: Convivencia as Structural, Cultural, and Sexual Ideal, Newark, Juan de la Cuesta, pp. 83-106.

Riquer, M. de (1985) Isabel de Villena. Història de la literatura catalana, Esplugues de Llobregat, Ariel, pp. 453-484, vol. III.

Roig, J. (2010) Spill de Jaume Roig (Peirats, A.I. ed.), València, Acadèmia Valenciana de la Llengua, 2 vols.

Roig Gironella, S.I. (1975) Antoni Canals, Scala de contemplació, Barcelona, Fundación balmesianaBiblioteca Balmes, pp. 1-57.

Sales, A. (1761) Historia del real monasterio de la Santísima Trinidad, religiosas de Santa Clara de la Regular Observancia fuera de los muros de la ciudad de Valencia, València, J. E. Dolz, Impremta del Santo Oficio.

Saxònia, L. de (1474) Vita Ihesu Christi, Estrasburg, Eggesteyn.

- (1496) Meditationes vitae Christi, Lo primer del Cartoxà o Vida de Jesús, trelladat per Johan Roiç de Corella, València, BGH. Disponible en

http://trobes.uv.es/tmp/_webpac2_1461446.7691

Speculum bumanae salvationis (SHS) Lutz, J. i Perdrizet, P. (eds.) (1907-1909). Texte critique. Traduction inedite de Jean Mielot (1448). Les sources et l'influence iconographique, principalement sur l'art alsacien du XIV siècle, Mülhausen, Ernest Meininger.

Tubach, F. (1969) Index exemplorum. A bandbook of mediaeval religious tales, Helsinki, FFC.

Twomey, L. K. (2013) The Fabric of Marian Devotion in Isabel de Villena's Vita Christi, Woodbridge / New York, Tamesis. 
Anna Isabel Peirats Navarro. La Vita Christi d'Isabel de Villena, misericòrdia restaurativa i profitosa doctrina al servei de la meditació

Varazze, J. da (2007) Legenda aurea. Con le miniature del codice Ambrosiano C 240 inf. (Maggioni, G.P. ed. / Stella F., trad.), Firenze, SISMEL-Ed. del Galluzzo/ Biblioteca Ambrosiana Milano, Edizione Nazionale dei Testi Mediolatini, 20, Serie II, 2 vol.

Vicent Ferrer, Sant (1929) Quaresma de Sant Vicent Ferrer, predicada a València l'any 1413 (Sanchis Sivera, J. ed.), Barcelona, Institució Patxot.

—_. (1932-134) Sermons (Sanchis Sivera, J. ed.), Barcelona, Barcino, 2 vol. . (1975-1988) Sermons (Schib, G. ed.), Barcelona, Barcino, 4 vol.

Villena, I. de (1916) Isabel de Villena Llibre anomenat Vita Christi (Miquel i Planas, R. ed.), Barcelona, Biblioteca Catalana, 3 vol.

—. (1995) Vita Christi (Hauf, A. ed.), Barcelona, Edicions 62.

(2011) Isabel de Villena (Elionor d'Aragó i de Castella), Vita Christi (Escartí, V. J. ed.), València, Institució Alfons el Magnànim. 